\title{
MANAGEMENT OF CHEMO- AND RADIOTHERAPY INDUCED ORAL MUCOSITIS WITH LOW-ENERGY LASER: INITIAL RESULTS OF A.C. CAMARGO HOSPITAL
}

\author{
MANEJO DA MUCOSITE ORAL INDUZIDA POR QUIMIOTERAPIA E \\ RADIOTERAPIA COM LASER DE BAIXA POTÊNCIA: RESULTADOS INICIAIS \\ DO HOSPITAL A.C. CAMARGO
}

\author{
Renata Lazari SANDOVAL \\ Resident of the Department of Stomatology at A.C. Camargo Hospital. \\ Daniel Henrique KOGA \\ Resident of the Department of Stomatology at A.C. Camargo Hospital. \\ Lígia Schmitd BULOTO \\ Resident of the Department of Stomatology at A.C. Camargo Hospital. \\ Ricardo SUZUKI \\ Resident of the Department of Stomatology at A.C. Camargo Hospital. \\ Luciano Lauria DIB \\ Professor of Stomatology at UNIP.
}

\begin{abstract}
$B$ ackground. Oral mucositis is a common complication of some malignancies treatment, causing therapeutic modifications due to patient's debilitation, which often interferes with the prognosis of the disease. Many attempts have been made to find an optimal treatment or preventive method to minimize the severity of oral mucositis. Several studies have shown good results with the use of low-energy laser, with the aim of accelerating the process of wound healing and promoting pain relief. Methods. Patients $(n=18)$ who developed oral mucositis during chemotherapy and/or radiotherapy were submitted to low-energy laser applications until cessation of symptoms. Mucositis severity was scored by an oral mucositis scale based on clinical features and by an oral toxicity scale from the National Cancer Institute based on the ability to swallow; pain severity was scored by subjects on a visual analogue scale before and after the applications. Results. Immediate pain relief was achieved in $66.6 \%$ of the patients after the first application. Based on the functional scale, mucositis grade III (not capable to eat solids) was reduced in $42.85 \%$ of the cases. According to the scale based on the clinical features, mucositis grade IV (ulcerative lesions) was reduced in $75 \%$ of the patients that presented this grade of mucositis at the beginning of laser therapy. Conclusions. Low-energy laser was well-tolerated and showed beneficial effects on the management of oral mucositis, improving the quality of life during the oncologic treatment.
\end{abstract}

UNITERMS: Low-energy laser; Soft laser; Oral mucositis.

\section{INTRODUCTION}

Oncologic treatment often involves the use of radiotherapy and/or chemotherapy. A common acute complication of this kind of therapy is oral mucositis, which has a great impact in patient's quality of life during treatment and sometimes may lead to treatment interruptions, resulting in severe consequences in terms of tumor response.
Approximately $60 \%$ of patients receiving conventional radiotherapy for head and neck cancer and more than $90 \%$ of patients submitted to combined therapy (concomitant chemotherapy and radiotherapy) or altered fractionation are expected to develop severe oral mucositis ${ }^{9}, 11$. In addition, up to $40 \%$ of chemotherapy patients develop oral mucositis, mainly when regimens include 5-FU, methotrexate, cisplatin ${ }^{17}$. Besides 
all the local discomfort caused by oral mucositis, the ulcerative lesions bring about a high risk of microbial invasion, predisposing to local and systemic infections that can be lifethreatening ${ }^{3,12}$

The pathogenesis of oral mucositis is linked to the decreased cell renewal in the basal layers of the epithelium, due to the effects of chemotherapy and radiotherapy. According to Sonis ${ }^{18}$, oral mucositis progresses through four physiologic phases: 1) inflammatory or vascular, 2) epithelial, 3) ulcerative and bacteriological, and 4) healing phase.

Many agents have been tested for prevention and treatment of mucositis: oral glutamine supplementation ${ }^{10}$, sucralfate ${ }^{5}$, steroids, immunoglobulin, amifostine ${ }^{6}$, antibiotic lozenges, chlorhexidine rinses ${ }^{8}$, vitamin $\mathrm{E}^{21}$, salt and soda mouthwash, but none of them showed optimal symptom relief and reduction in the intensity or duration of the lesions.

Nowadays, management of oral mucositis is mostly based on palliation of the symptoms (topical anesthetics, antiinflammatories, systemic analgesic drugs) and prevention of secondary infections (antimicrobial agents). However, considering Sonis' concept ${ }^{18}$, which describes the physiologic progression of mucositis, it is mandatory to consider treatments with mechanisms of action that match with those biological mechanisms involved in each phase of mucositis. Biron, et al. ${ }^{4}$ (2000) described very well all the physiologic phases and the respective treatment options. The most promising procedure seems to be the use of Low-Energy Laser.

Several trials have demonstrated the use of Low-Energy Laser (LEL) in the management of oral mucositis. Laser applications were associated with time of onset delay, peak severity attenuation and shortened duration of the lesions. Previous studies have attributed the enhancement of wound healing and pain relief potential of LEL to microscopic and molecular findings as increased cell division and modification of nerve conduction via the release of endorphins and enkephalins, respectively ${ }^{1,2,7,16}$.

The aim of the present study is to evaluate the benefits of low-energy laser therapy in the management of oral mucositis, as well as the acceptance and compliance of this technique by the patients treated at our institution.

\section{Patients and Methods}

A preliminary prospective study was conducted with all the patients who developed chemo- and/or radio-induced oral mucositis from February 2002 to July 2002. The patients were referred to the Department of Stomatology as soon as symptoms related to mucositis started.

Patients consisted of 8 females and 10 males, aged 4-82, who were undergoing chemotherapy and/or radiotherapy for the treatment of 9 head and neck cancers ( 8 oral squamous cell carcinomas and 1 nasopharyngeal carcinoma), 5 leukemias, 1 non-Hodgkin lymphoma, 1 Hodgkin's disease and 3 other sarcomas. Nine patients were receiving chemotherapy, 3 patients were being submitted to radiotherapy in the head and neck field, 5 patients were undergoing concomitant chemotherapy and radiotherapy, and 1 patient had been enrolled to conditioning chemotherapy for bone marrow transplantation.
Laser applications were performed daily (660nm wavelength, power $30 \mathrm{~mW}, 2$ Joules $/ \mathrm{cm}^{2}$ ) until cessation of symptoms. The treatment time for each application point, which was coincident with the oral lesion, was 1 minute and 6 seconds. The average energy density delivered for each application point was 2 Joules $/ \mathrm{cm}^{2}$. The total amount of time of each session of laser therapy depended on the extension and number of lesions. Mucositis severity was scored by a scale based on clinical features, and by an Oral Toxicity Scale from the National Cancer Institute based on the ability to swallow (Table 1); pain severity was scored by subjects on a visual analogue scale before and after the applications.

\section{RESULTS}

Immediate pain relief after laser application was achieved in 12 patients $(66.6 \%)$ during the first application. At the last application, $16(88.8 \%)$ patients referred immediate pain relief. On the other hand, during the first application, 6 patients $(33.3 \%)$ did not refer any pain relief, which happened with only 2 patients at the last application (Figure 1).

According to the grading system based on functional impairments in the beginning of laser therapy, 2 patients presented mucositis grade I (11.1\%), 7 patients showed grade II (38.8\%), 7 patients grade III, and 2 patients grade IV. At the last application, 4 patients presented grade $\mathrm{I}(22.2 \%), 9$ patients grade II $(49.9 \%), 3$ patients grade III $(16.6 \%)$, and 2 patients grade IV $(11.1 \%)$. The number of patients receiving nutritional support did not show any decrease. Mucositis grade III was reduced in $42.85 \%$ of the cases that presented this oral status at the beginning of the therapy. In addition, the decrease of grade III (compromised ability to swallow) was associated with an important increase of grades I and II (Table 2).

Considering the classification of mucositis based on the clinical aspects, the initial evaluation of the patients showed 3 patients with mucositis grade II (16.6\%), 7 grade III (38.8\%), and 8 grade IV (44.4\%). At the end of laser therapy, 1 patient presented grade $0(5.5 \%), 4$ patients showed grade II (22.2\%), 11 had grade III $(61.1 \%)$ and 2 grade IV $(11.1 \%)$. Mucositis grade IV was reduced in $75 \%$ of the cases. The decrease in mucositis grade IV was associated with an increase in mucositis grade 0 , II and III, especially grade II (Table 2 ).

The number of applications ranged from 1 to 16 applications and the average number of applications per patient was 5.33 .

\section{DISCUSSION}

Our study was designed to evaluate the benefits of curative laser therapy in the management of oral mucositis, regarding the acceptance and compliance of this technique by the patients, with emphasis to pain reduction and attenuation of mucositis severity.

Experimental studies in animals and in vitro studies conducted during the 1990's have provided evidence that lowenergy lasers accelerate the process of wound healing. PourreauSchneider, et $\mathrm{al}^{14}$. (1989) reported a twofold increase in the 
number of gingival fibroblasts that had received laser irradiation compared to that of untreated controls. In addition, by means of transmission electron microscopy they observed that the laser induced modifications in the ultrastructure of the treated cells, causing mitochondrial hyperplasia and deposition of an abundant fibrillar matrix. Even though the precise mechanisms involved have not yet been elucidated, some possible partial explanations have been reported. A number of cellular components manifest photoactivation by bioelectrical reactions. The energy absorbed at the mitochondrial level could be

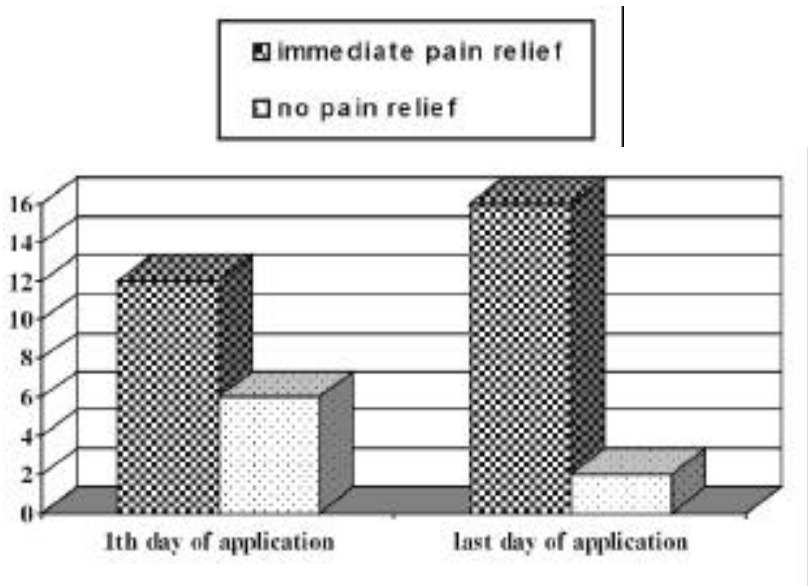

FIGURE 1- Pain relief after laser application available for photochemical reactions. The absorption of photons by cytochromes, present in large numbers in mitochondrial crests, could lead to an enhancement of protein synthesis ${ }^{15}$.

The recent literature reveals that the prophylactic laser therapy seems to be more effective than the curative approach, but there are also good results showing pain relief achieved by curative laser applications. In 1992, Pourreau-Schneider, et al. ${ }^{16}$ published a preliminary report showing the benefits of LEL therapy in cancer patients receiving high-dose fluorouracil. Several malignancies were included in the study, including head and neck cancer, breast, colon and others. The patients were divided in three groups: a control group (without laser therapy), a preventive group (laser therapy prior to and during chemotherapy) and a curative group. The incidence and severity of oral mucositis were calculated according to the total cycles of chemotherapy. In the control group, mucositis occurred in $43 \%$ of 51 chemotherapy cycles. In the curative group, the time to repair grade IV lesions (ulcerations, no oral uptake) was reduced from a mean of 19.3 days in the control patients to 8.1 days. In the preventive group, only low-grade mucositis occurred.

The data obtained in our study showed an improvement of the oral status at the end of laser therapy, considering both aspects: functional and clinical. Functional mucositis grade III (cannot eat solids/liquids) was reduced in $42.85 \%$ of the cases that presented this grade at the beginning of therapy. In addition,

TABLE 1- Oral mucositis grading scores

\begin{tabular}{lccccc}
\hline & & & Grade & \\
\hline Type of score & $\mathbf{0}$ & I & II & III & IV \\
\hline $\begin{array}{l}\text { Clinical } \\
\text { parameters }\end{array}$ & no change & whitish aspect & erythema & white coating & ulcers \\
$\begin{array}{l}\text { Functional } \\
\text { impairments }\end{array}$ & no symptoms & soreness & mild pain/can & can't eat solids/ & require nutritional \\
& & & solids & liquids & eat support \\
\hline
\end{tabular}

TABLE 2- Oral status before and after laser therapy, according to clinical and functional aspects

\section{Number of patients}

$\begin{array}{lllll}\text { Mucositis graduation } & \text { IS } & \text { FS } & \text { IS } & \text { FS }\end{array}$

\begin{tabular}{lllll}
\hline Grade 0 & 0 & 0 & 0 & 1 \\
Grade I & 2 & 4 & 0 & 0 \\
Grade II & 7 & 9 & 3 & 4 \\
Grade III & 7 & 3 & 7 & 11 \\
Grade IV & 2 & 2 & 8 & 2 \\
\hline
\end{tabular}

IS, initial oral status; FS, final oral status. 
clinical mucositis grade IV (ulcers) was reduced in $75 \%$ of the cases. Although it was possible to observe a reduction in mucositis severity, it did not allow an evaluation of the exact duration of the lesions, since the patients were referred to our department only when they became symptomatic and laser applications were suspended as soon as pain cessation was achieved, even though there was still clinical evidence of mucositis. The number of applications needed for the achievement of symptoms cessation ranged from 1 to 16 applications and the average number of applications per patient was 5.33.

Radio- and chemo-induced oral mucositis have different peaks of severity and improvement. Radio-induced oral mucositis may appear after 3-4 weeks of treatment, and their evolution is progressive if radiation therapy is not ceased. On the other hand, oral mucositis related to chemotherapy tends to increase 1-2 weeks after the start of treatment, followed by improvement. ${ }^{13}$ In our sample, 9 patients were submitted to chemotherapy and 8 patients were submitted to radiotherapy alone or in combination with chemotherapy.

Bensadoun, et al. ${ }^{2}$ (1999) performed a randomized phase III trial in which laser therapy was administered in a preventive and curative form following the 7-week treatment of patients with head and neck cancer receiving radiotherapy alone. The group of patients that did not receive laser therapy (L-) showed mucositis grade 3 (confluent ulcers, liquid diet only; according to $\mathrm{WHO}$ staging) during $35.2 \%$ of the weeks, and this number fell to $7.6 \%$ in the group that received the laser $(\mathrm{L}+)$. In addition, the frequency of severe pain was $23.8 \%$ in the L- group and $1.9 \%$ in the L+ group. In the present study, despite the elevated number of patients that presented grade 3 mucositis (white coating) at the end of laser therapy, this finding is probably related to the healing process of the lesions, since there were no associated symptoms. This fact reveals an old problem related to effective scoring of mucositis. Sonis, et al. ${ }^{19}$ (1999) demonstrated a strong correlation between objective patterns (clinical appearance of oral mucositis) and symptoms during a validation study of an oral mucositis scoring system, however, it could not be shown in ours. Other validation studies with enough tools and relevant endpoints are needed.

Patients undergoing bone marrow transplantation (BMT) are also widely approached by low-energy laser trials. Cowen, et al. ${ }^{7}$ (1997) showed a 33\% reduction of severe mucositis in patients submitted to laser therapy during conditioning regimen for BMT. The assessment of oral pain was based on the need of morphine administration, which was significantly reduced by laser applications $(p=0.05)$. This finding is in agreement with the study conducted by Bensadoun ${ }^{2}$. In our study, the pain severity was scored in a subjective way by the patients. It was assessed before and after laser applications. Immediate pain relief after laser application was referred by $66.6 \%$ of the patients during the first application, and at the last application, it happened with $88.8 \%$ of the patients. In a double-blind study of pain relief due to LEL, a large increase in the urinary excretion of 5-hydroxyindoleacetic acid was found in patients who received LEL treatment, what suggested that LEL treatment may affect the serotonin metabolism. ${ }^{22}$ Another possible mechanism related to the analgesic effect of LEL was described by Snyder-Mackler and Bork in 1988. ${ }^{20}$ They documented a physical finding concerning an interference in the sensory nerve transmission caused by laser irradiation. However, in our study, persistent oral pain was demonstrated in $12.2 \%$ of the patients, and this could be a consequence of the association of other pathologies, such as herpes infection.

Aspects related to the duration of mucositis and peak severity attenuation were not statistically calculated and discussed in our study because of the diversity of pathologies and respective treatments present in our sample. The age range, distribution of patients by diagnosis and therapeutic regimens (chemotherapy, radiotherapy, concomitant chemotherapy and radiotherapy, conditioning for blood marrow transplantation) were variables that were extremely difficult to control in such a small sample. In addition, several factors could influence the development, severity and duration of oral mucositis, including the underlying disease, treatment schedule, doses, combination and duration of exposure to drugs and/or ionizing radiation, systemic clearance of drugs, local and microbial irritation, among others.

Finally, there are many uncontrolled reports of potential benefits of low-energy lasers, but only a few controlled studies have been published. Despite the small and heterogeneous characteristic of our sample, it is evident that LEL is a noninvasive technique that seems to promote pain relief and reduce the severity of oral mucositis; for this reason, patients present a high acceptance and compliance to this therapy, even the youngest ones. After the present study, the use of LEL in the management of oral mucositis became a routine at our institution. Further randomized controlled trials with homogeneous samples and different laser application schedules should be conducted with the aim to develop effective protocols to treat and prevent such debilitating complication as oral mucositis.

\section{ACKNOWLEDGMENT}

We would like to thank the assistance of the residency students Ana Laura Soares and Mariana Curado in the conclusion of the present work.

\section{RESUMO}

Mucosite é a complicação oral mais comum do tratamento de algumas doenças malignas, podendo causar a necessidade de modificações terapêuticas, o que pode interferir com o prognóstico da doença. Muitas tentativas têm sido feitas com o intuito de desenvolver um tratamento ou método preventivo para minimizar a severidade da mucosite oral. Vários estudos têm mostrado bons resultados com o uso do laser de baixa potência, devido à aceleração do processo de cicatrização das lesões e da promoção do alívio da dor. Métodos: Os pacientes que desenvolveram mucosite oral durante tratamento quimioterápico e/ou radioterápico $(\mathrm{n}=18)$, foram submetidos a aplicações de laser de baixa potência até que fosse atingida a cessação dos 
sintomas. A severidade da mucosite foi avaliada através de uma escala baseada em características clínicas e de uma escala para avaliação de toxicidade oral desenvolvida pelo Instituto Nacional do Cancer, baseada na habilidade de deglutição; a dor foi avaliada através de uma escala visual, antes e depois de cada aplicação. Resultados: Alívio imediato da dor após a primeira aplicação foi referido por $66.6 \%$ dos pacientes. Com base na escala funcional, mucosite grau III (incapacidade de ingerir alimentos sólidos) foi reduzida em $42.85 \%$ dos casos. De acordo com a escala baseada em aspectos clínicos, mucosite grau IV (presença de úlceras) foi reduzida em $75 \%$ dos pacientes que apresentavam essa condição no início da terapia com laser. Conclusões: O laser de baixa potência foi bem tolerado pelos pacientes, e mostrou efeitos benéficos durante o manejo da mucosite oral, melhorando a qualidade de vida dos pacientes durante o tratamento oncológico.

UNITERMOS: Laser de baixa potência; Mucosite oral.

\section{REFERENCES}

1- Barasch A, Peterson DE, Tanzer JM, D'Ambrosio JA, Nuki K, Schubert MM, et al. Helium-neon laser effects on conditioninginduced oral mucositis in bone marrow transplantation patients. Cancer 1995 Dec 15; 76(12): 2550-6.

2- Bensadoun RJ, Franquin JC, Ciais G, Darcourt V, Schubert MM, Viot $\mathrm{M}$, et al. Low-energy $\mathrm{He} / \mathrm{Ne}$ laser in the prevention of radiationinduced mucositis. A multicenter phase III randomized study in patients with head and neck cancer. Support Care Cancer 1999; 7(4): $244-52$.

3- Bergmann OJ. Oral infections and fever in immunocompromised patients with haematologic malignancies. Eur J Clin Microbiol Infect Dis 1989; 8(3): 207-13

4- Biron P, Sebban C, Gourmet R, Chvetzoff G, Philip I, Blay JY. Research controversies in management of oral mucositis. Support Care Cancer 2000; 8(1): 68-71.

5- Carter DL, Hebert ME, Smink K, Leopold KA, Clough RL, Brizel DM. Double blind randomized trial of sucralfate vs placebo during radical radiotherapy for head and neck cancers. Head Neck 1999; 21(8): 760-6.

6- Chauncey TR, Gooley TA, Lloid ME, Schubert MM, Lilleby K, Holmberg L, et al. Pilot trial of cytoprotection with amifostine given with high-dose chemotherapy and autologous peripheral blood stem cell transplantation. Am J Clin Oncol 2000; 23(4): 406-11.

7- Cowen D, Tardieu C, Schubert M, Peterson D, Resbeut M, Faucher $\mathrm{C}$, et al. Low energy Helium-Neon laser in the prevention of ora mucositis in patients undergoing bone marrow transplant: results of a double blind randomized trial. Int J Radiat Oncol Biol Phys 1997 Jul 1; 38(4): 697-703.

8- Dodd MJ, Dibble SL, Miaskowski C, MacPhail L, Greenspan D, Paul SM, et al. Randomized clinical trial of the effectiveness of 3 commonly used mouthwashes to treat chemotherapy-induced mucositis. Oral Surg Oral Med Oral Pathol Oral Radiol Endod 2000; 90(1): 39-47.

9- Horiot JC, Le Fur R, N'Guyen T, Chenal C, Schraub S, Alfonsi S, et al. Hyperfractionation versus conventional fractionation in oropharyngeal carcinoma: final analysis of a randomized trial of the EORTC cooperative group of radiotherapy. Radiother Oncol 1992 Dec; 25(4): 231-41.
10- Klimberg VS, Souba WW, Dolson DJ, Salloum RM, Hautamaki RD, Plumley DA, et al. Prophylactic glutamine protects the intestinal mucosa from radiation injury. Cancer 1990 Jul 1; 66(1): 62-8.

11- Merlano M, Corvo R, Margarino G, Benasso M, Rosso R, Sertoli $\mathrm{MR}$, et al. Combined chemotherapy and radiation therapy in advanced inoperable squamous cell carcinoma of the head and neck. The final report of a randomized trial. Cancer 1991 Feb 15; 67(4): 915-21.

12- Novakova IR, Donnelly JP, De Pauw B. Potential sites of infection that develop in febrile neutropenic patients. Leuk Lymphoma 1993; 10(6): 461-7.

13- Öhrn KE, Wahlin YB, Sjoden PO. Oral status during radiotherapy and chemotherapy: a descriptive study of patient experiences and the occurrence of oral complications. Support Care Cancer 2001; 9(4): 247-57.

14- Pourreau-Schneider N, Soudry M, Remusat M, Franquin JC, Martin PM. Modifications of growth dynamics and ultrastructure after helium-neon laser treatment of human gingival fibroblasts. Quintessence Int 1989; 20(12): 887-93.

15- Pourreau-Schneider N, Ahmed A, Soudry M, Jacquemier J, Kopp F, Franquin JC, Martin PM. Helium-neon laser treatment transforms fibroblasts into myofibroblasts. Am J Pathol 1990; 137(1): 171-8.

16- Pourreau-Schneider N, Soudry M, Franquin JC, Zattara H, Martin $\mathrm{PM}$, Ciais G, et al. Soft-laser therapy for iatrogenic mucositis in cancer patients receiving high-dose fluorouracil: a preliminary report. J Natl Cancer Inst 1992 Mar 4; 84(5): 358-9.

17- Scully C, Epstein JB. Oral health care for the cancer patient. Eur J Cancer B Oral Oncol 1996 Sep; 32B(5): 281-92.

18- Sonis ST. Mucositis as a biological process: a new hypothesis for the development of chemotherapy-induced stomatotoxicity. Oral Oncol 1998; 34(1): 39-43.

19- Sonis ST, Eilers JP, Epstein JB, LeVeque FG, Liggett WH Jr, Mulagha MT, et al. Validation of a new scoring system for the assessment of clinical trial research of oral mucositis induced by radiation or chemotherapy. Mucositis Study Group. Cancer 1999 May 15; 85(10): 2103-13.

20- Snyder-Mackler L, Bork CE. Effect of helium-neon laser irradiation on peripheral sensory nerve latency. Phys Ther 1988; 68(2): 223-5.

21- Wadleigh RG, Redman RS, Graham ML, Krasnow SH, Anderson A, Cohen MH. Vitamin E in the treatment of chemotherapy-induced mucositis. Am J Med 1992; 92(5): 481-4.

22- Walker J. Relief from chronic pain by low power laser irradiation. Neurosci Lett 1983 Dec 30; 43(2-3): 339-44.

Recebido para publicação em: 08/04/2003

Enviado para reformulações em: 17/06/2003

Pronto para publicação em: 17/09/2003

Autor correspondente:

Dra. Renata Lazari Sandoval

Departamento de Estomatologia do Hospital A.C. Camargo

Rua Prof. Antônio Prudente, $\mathrm{n}^{0} 211$

CEP 01509-900 São Paulo-SP

Tel: (11) 3272-5129 Fax: (11) 3272-5088.

E-mail:renata.odonto@uol.com.br 